\title{
Giant Cell Tumor of the Phalanx of Finger: Case Reports
}

\author{
Pamudji Utomo'), Mujaddid Idulhaq'), Ambar Mudigdo², \\ Okkie Mharga Sentana')
}

1)Department of Orthopaedic and Traumatology, Prof. Dr. R. Soeharso

Orthopaedics Hospital/Faculty of Medicine, Universitas Sebelas Maret

${ }^{2)}$ Department of Pathology and Anatomy, Faculty of Medicine, Universitas Sebelas Maret

\begin{abstract}
Background: Giant cell tumor (GCT) of bone arising from aphalanx of finger is extremely rare. Although, the occurrence of GCT in the hands is a rare, it has been reported that GCT of the small bones (small-bone GCT) carries a higher risk of local recurrence and metastasis than conventional GCT.

Subjects and Method: We report two cases of GCT arising from a phalanx of a hand finger. First patient was treated with wide excision of the tumor and fusion with fibular bone graft with the help of a K-wire. Second patient was treated by excision of tumour (Curretage) with allograft bonegraft for bone defect.

Results: At their most recent follow-ups (4 months, respectively), both were recurrence free and had returned to their previous occupational and recreational activities.

Conclusion: The effectiveness of these methods in the treatment and prevention of recurrence is still under discussion and there is no gold standard for treating GCT.
\end{abstract}

Keywords: GCT, phalanx of finger, excision, illiac crest bonegraft, allograft

\section{Correspondence:}

Pamudji Utomo. Department of Orthopaedic and Traumatology, Faculty of Medicine, Universitas Sebelas Maret. Jl. Ir. Sutami 36A, Surakarta, Central Java. Email: utomodr@yahoo.com.

\section{BACKGROUND}

Giant cell tumour (GCT) in bone is usually located in the ends of the long bone, accounting for approximately for $5 \%$ of primary bone tumour. Only 2-5\% of GCTs are located in the hand. (Athanasian et al., 1997; Averill et al., 1980; Yanagisawa et al., 2011). Giant cell tumor is commonly seen in the epi-metaphyseal ends of long bones in young adults (Frassica et al., 1993). In the hand region, GCTs are primarily located in the metacarpal bones; second, they are located in the phalanges and, rarely, they are located within the thumb (Reichert et al., 2017).

Giant celltumor of bone (GCT) is a benign aggressive, locally recurrenttumor with a low metastatic potential (4\%-8\%) (Malawer et al., 2012).
The natural history of GCTs varies widely and can range from local bony destruction to local metastasis, metastasis to the lung, metastasis to lymph nodes, or malignant transformation (Moon et al., 2012).

Although, the occurrence of GCT in the hands is a rare, it has been reported that GCT of the small bones (small-bone GCT) carries a higher risk of local recurrence and metastasis than conventional GCT. The treatment of GCT using intraregional procedures includes the following: curettage and bone grafting or excisional procedures, such as local excision, wide excision, amputation, and ray resection.1 Intralesional curettage may be improved with local adjuvant treatment, such as phenol (Becker et al., 2008; Trieb et al., 
2001) alcohol, (Errani et al., 2010; Jones et al., 2006), and cryotherapy (Marcove et al., 1978; Malawer et al., 1999). Bone defects can be supplemented with polymethylmethacrylate (PMMA) cement, autograft, allograft, or bone substitute (Algawahmed et al., 2010). In addition, treatment can be enhanced with the use of monoclonal antibody (Thomas et al., 2010), calcitonin (Nouri et al., 2011), and bisphosphonates (Balke et al., 2010).

Here, we report two case of GCT phalanx of finger that had been treated with wide excision and reconstruction with fibular graft and the other case with curretage and allograft bonegraft.

CASE SUMMARY

\section{CASE 1}

A 54 year old Female presented with swelling of the index finger of dominant right hand since one and a half years ago. On careful history taking and review of old record, one and a half years ago her index finger was squezzed at the window and become swelling until now. 5 months before admission, she came at other hospital with the same swelling which was however smaller in size and had been performed open biopsy with the result is Giant cell tumour. But after that, she did not report back and over the time the swelling had increased in size. There was not any pain or night pain over her index finger. From physical examination, there was lump with size $5 \times 4 \times 3 \mathrm{~cm}$, ulcer, and swelling over her index finger. This lump was palpable solid, fixated, with irreguler and strict line border. At our center, we did his blood examination for hemoglobin, C-reactive protein, and erythrocyte sedimentation rate. Total and differential leukocyte counts and serum alkaline phosphatase levels which were within normal range. Radiograph showed expansile lytic lesion,with irregular sclerotic margin, cortical breach, extensive soft tissue extension, and complete destruction of the proximal phalanx of indexfinger. First open biopsy was suggestive of giant cell tumour. MRI showed a hypointense signal in the $\mathrm{T} 1 \mathrm{~W}$ sequences and heterogeneously hyperintense signal in the T2 $\mathrm{W}$ and PD sequences with extensive soft tissue involvement.

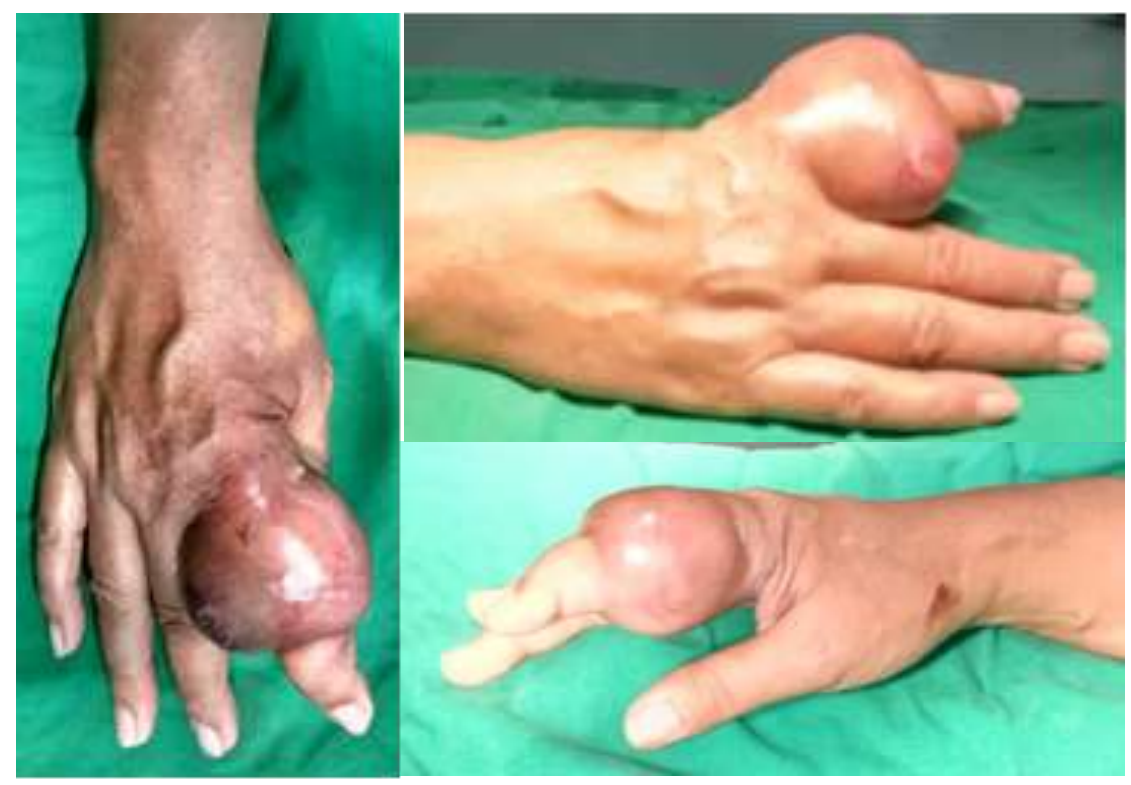

Figure 1. Clinical Picture of 2nd finger of the right hand 
Indonesian Journal of Medicine (2019), 4(1): 65-74

https://doi.org/10.26911/theijmed.2019.04.01.11
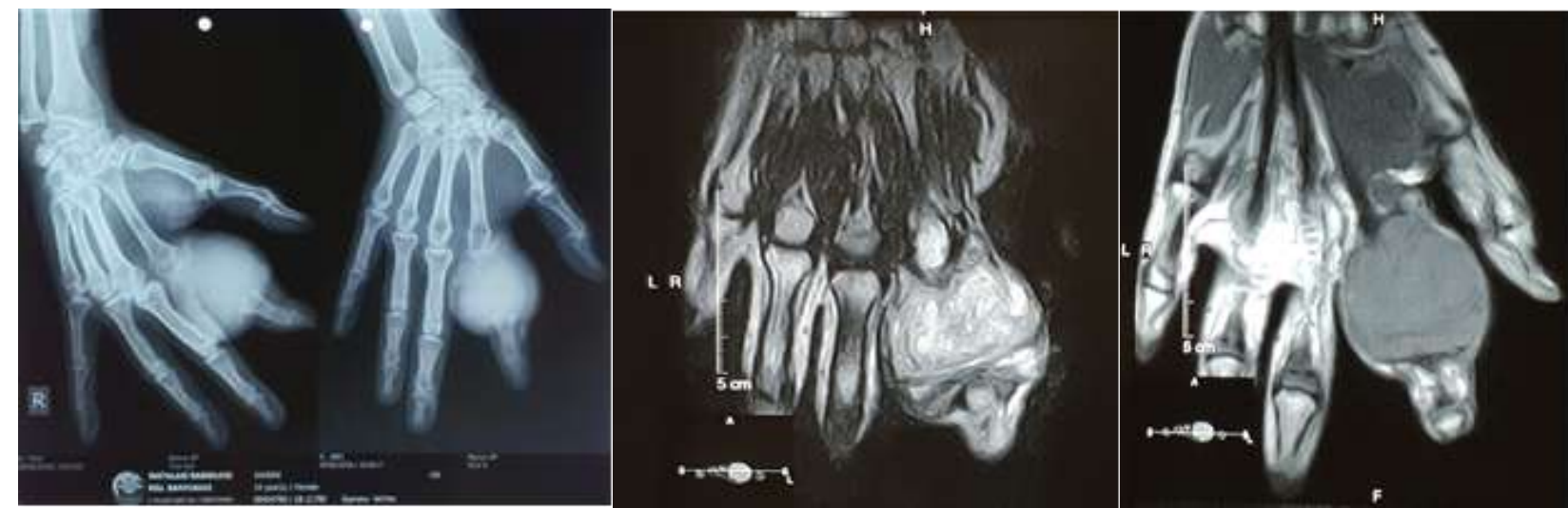

Figure 2. X-Ray and MRI of the 2nd finger of the right hand

Ultimately a diagnosis of Campanacci Grade III GCT of the proximal phalanx of index finger was made. After counseling the patient about the likelihood of a repeat recurrence and chances of local complications at the finger in the form of gangrene, infection, nonhealing of reconstruct, and recurrence, the patient was treated with wide excision of the proximal phalanx and fusion with fibular bone graft with the help of a K-wire. Histopathological examination reconfirmed that it was a giant cell tumor. On 6 month follow-up, his wound had healed and the finger had survived.

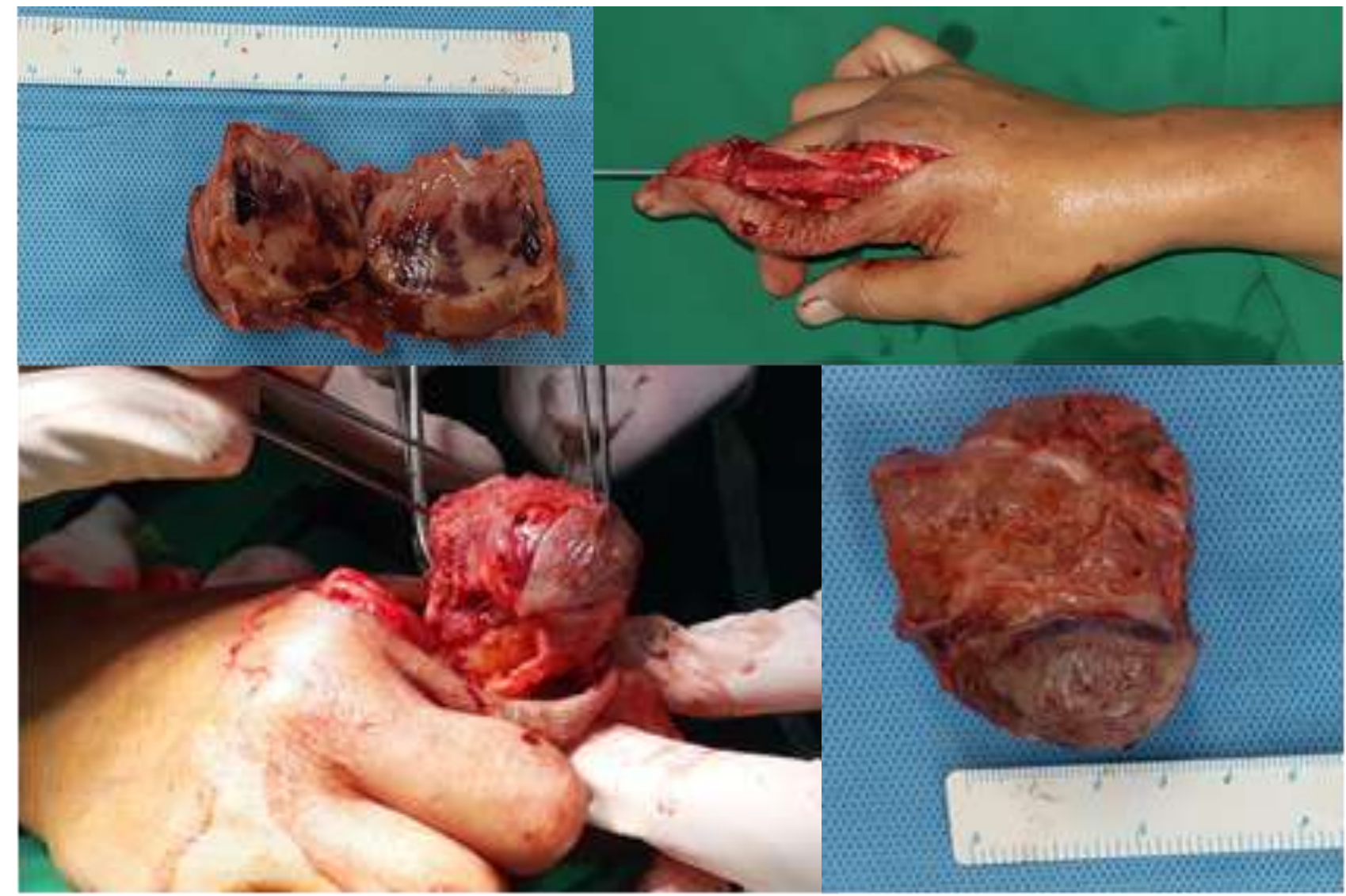

Figure 3. Excision of the mass and Fibular graft 


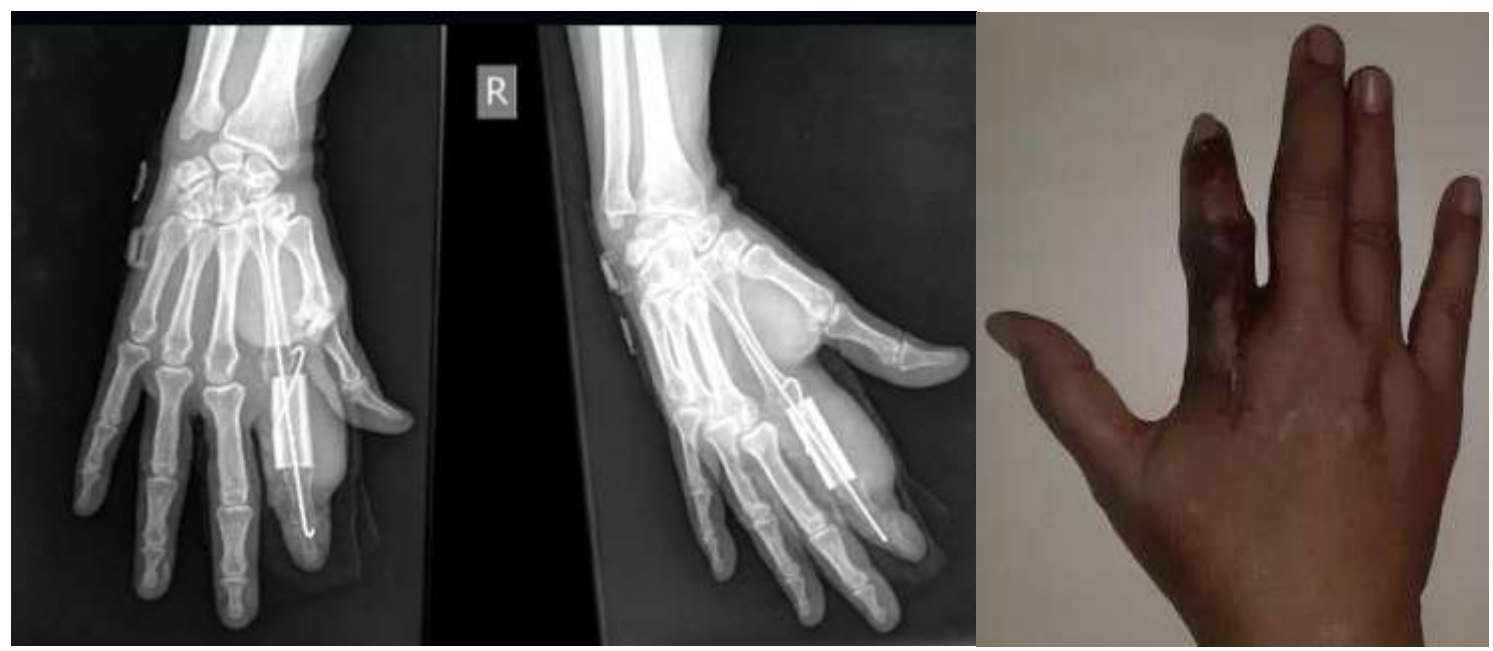

Figure 4. X-Ray post operative and follow up for 6 month

\section{CASE 2}

A 15-year-old boy presented with a fivemonth history of increasing swelling and pain in the fourth middle phalanx of his left hand with history of trauma, his ring finger hit by volley ball 6 month ago. In physical examination, there was a palpable, firm, and non-mobile $2 \times 1 \mathrm{x} 1 \mathrm{~cm}$ mass. The mass has been progressively growing with a natural pain. Proximal interphalengeal phalanx and metacarpophalengeal joints motion was impaired (Figure 5).
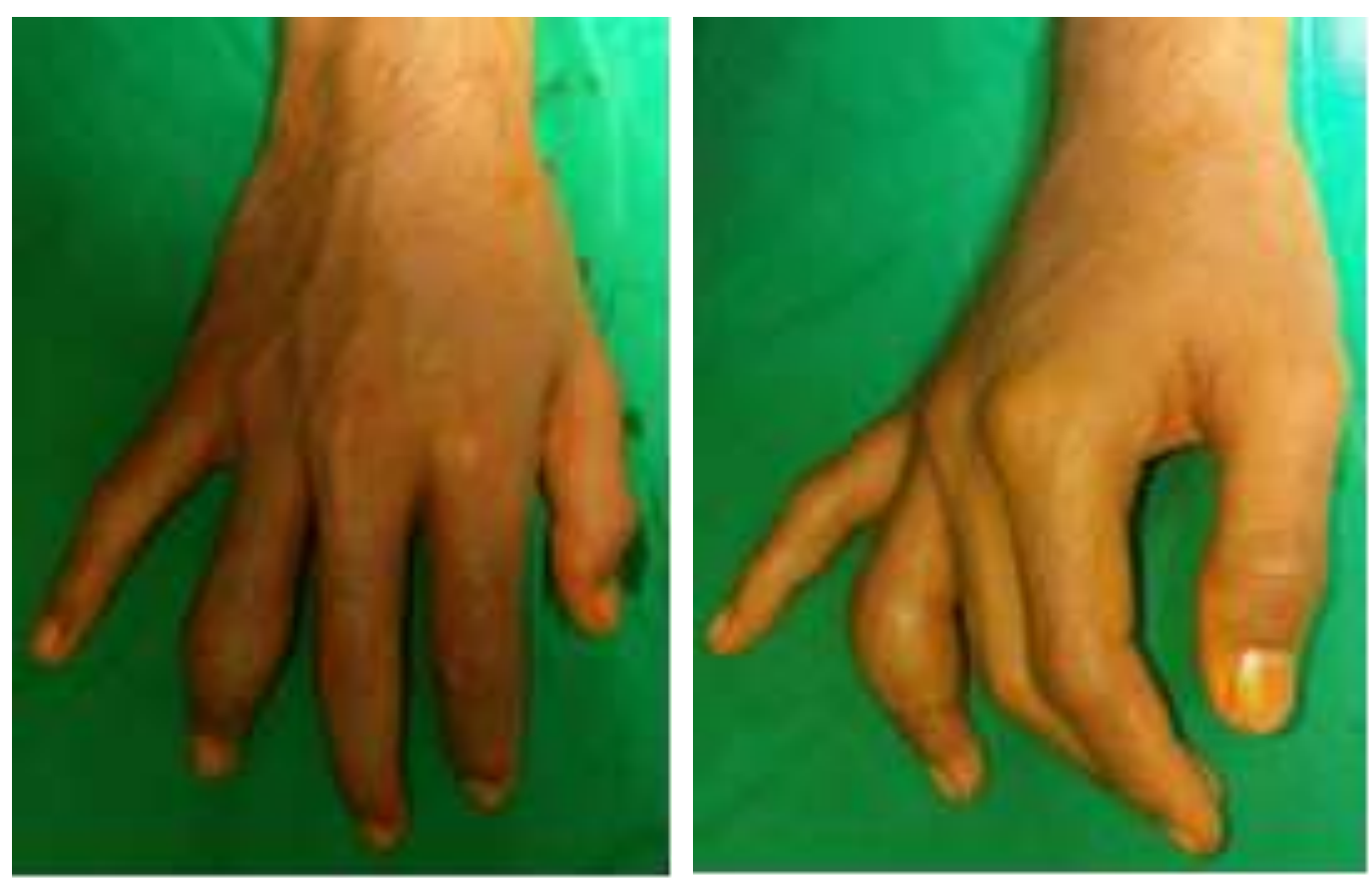

Figure 5. Clinical Picture of $4^{\text {th }}$ finger of right hand
Primary laboratory tests including cell blood count, ESR, and CRP were normal. Radiographs showed an expansive mixed lytic-blastic lesion of middle of the fourth phalanx bone with cortical destruction and soft tissue involvement. For the CT-Scan, there was lusen and septum lesion, expansile at metaphyseal region of the middle phalanx of fourth finger. It suggest Aneurysma Bone Cyst with differential diagnose Giant Cell Tumor (Figure 6). 
Indonesian Journal of Medicine (2019), 4(1): 65-74

https://doi.org/10.26911/theijmed.2019.04.01.11

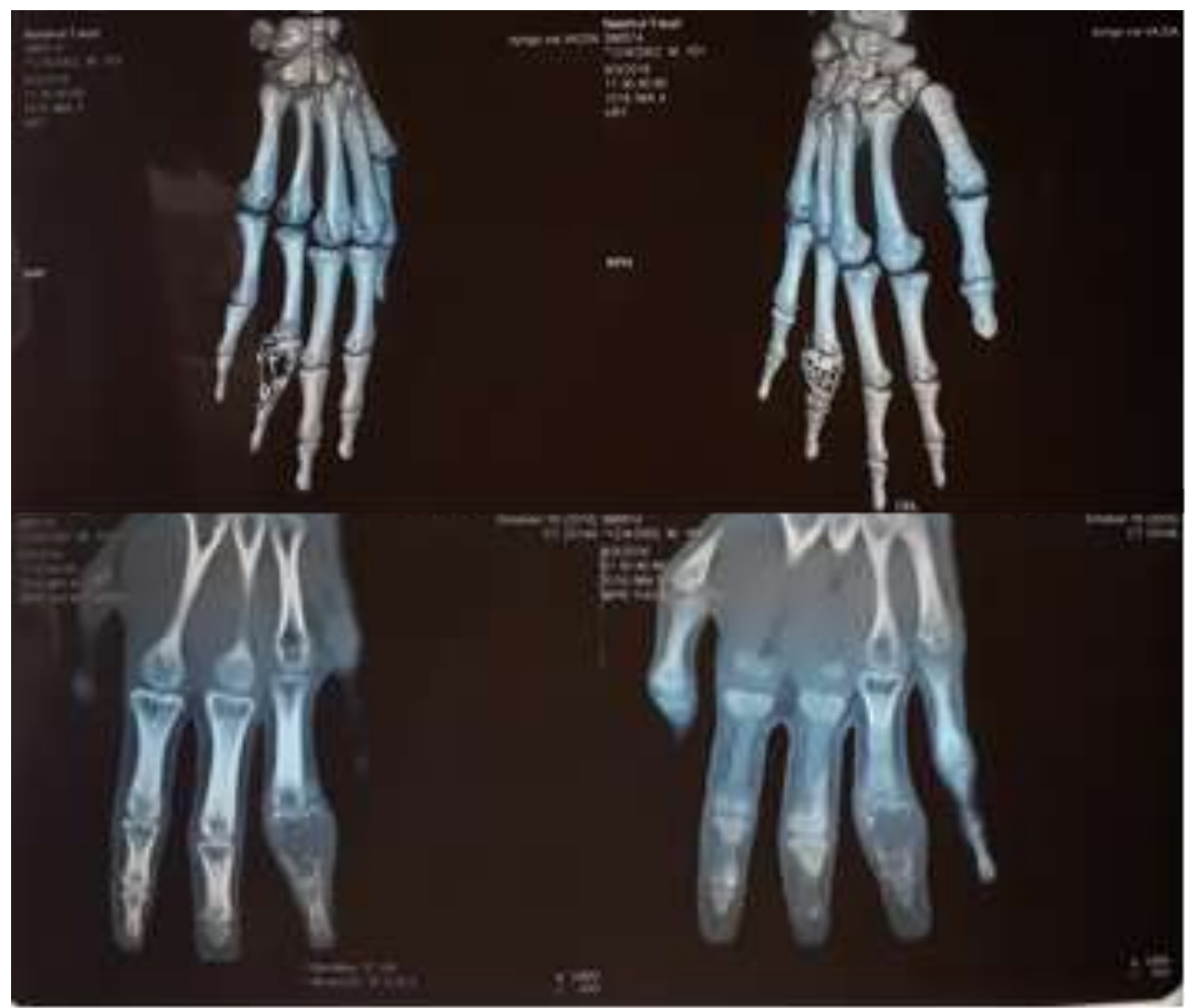

Figure 6. CT-Scan of the $4^{\text {th }}$ finger of right hand

Ultimately a diagnosis of Campanacci Grade III GCT of the proximal phalanx of index finger was made. After counseling the patient, complete excision of tumour (Curretage) with allograft bonegraft for bone defect was done. The tumour sent for histopathology. The histopathology confirmed the diagnosis of giant cell tumor with showed a benign tumour composed of small mononuclear cells which are round and spindle shape with pale cytoplasm and round nuclei along with osteoclast-like giant cells. Follow-up in the six months post operative day, has been satisfactory and patient informed of the need for follow up (Figure 7).

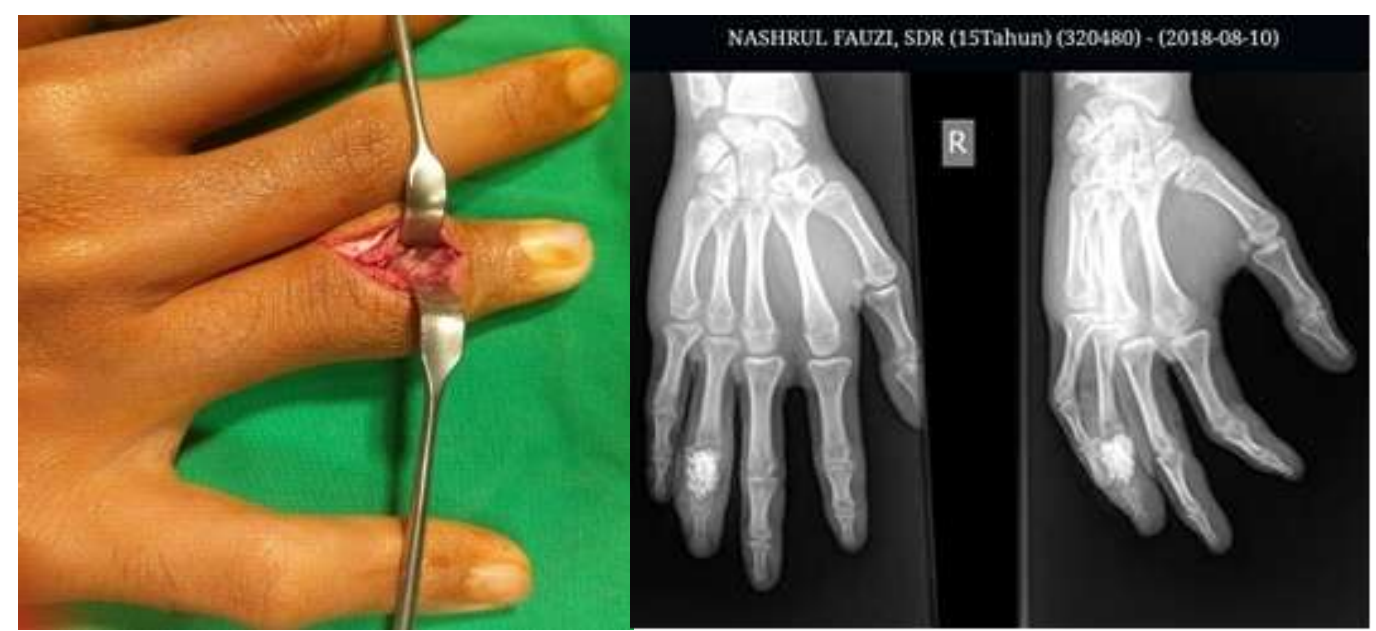

Figure 7. Curretage-bonegraft and X-ray Post Operation 


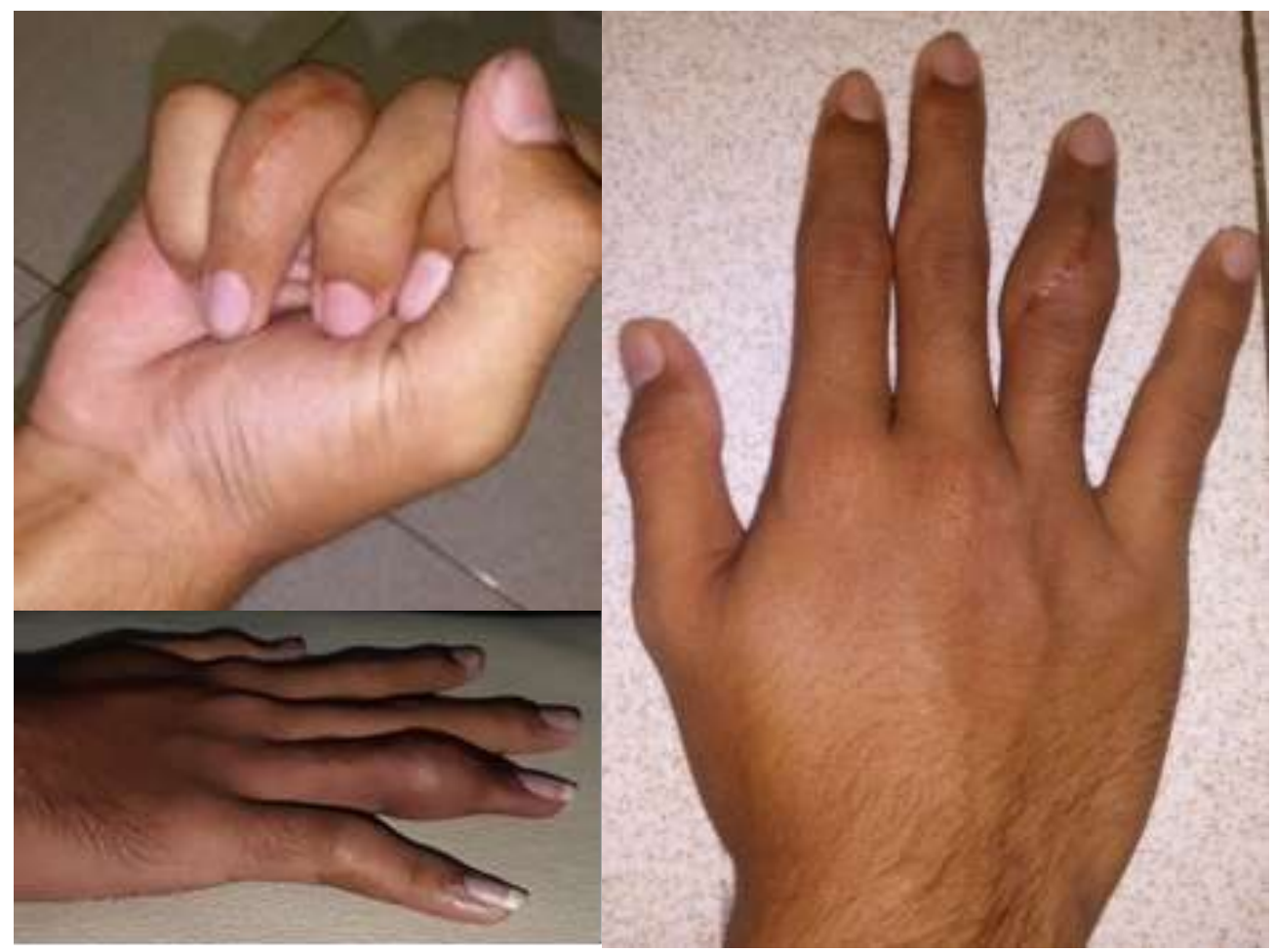

Figure 8. Follow up for 6 month

\section{DISCUSSION}

GCT of the hand is rare and is different from conventional GCT as recurrence is more common in the hand (Saikia et al., 2009). It is even rarer to encounter a GCT arising from the phalanges. More than 2,400 skeletal GCTs were reported in the literature, but not even 50 were found to be in the phalanges of the hand (Patel et al., 1987; Saikia et al., 2009; Bloodgood, 1919; Coley et al., 1958) reported only two cases of GCT arising from the phalanges in their series of 108 cases.

Goldenberg et al., (1970) in their analysis of 218 cases of GCT, reported six cases involving the phalanges. In another two large series of 568 and 327 cases of GCT, authors found only four and one cases of phalangeal involvement, respectively (Dahlin, 1996; Campanacci et al., 1987; Yasuda et al, 2008) reported a multicentric GCT of the hand involving a finger and the wrist. Benign metastasizing GCT of the hand has also been reported (Lopez Barea et al., 1992).

Giant cell tumors are generally considered benign, locally aggressive bone tumors. They may metastasize in up to $10 \%$ of patients, but usually do so only after repetitive local recurrences. When they occur in the hand they frequently cause severe bony destruction and extend into the surrounding soft tissues.

Primary Giant cell tumour involving the bones of the hand were occupying central location, expansile with paper-thin cortex, which differs from the usual eccentric location seen in Giant cell tumour of bones at other sites. GCT of bone hands is considered more aggressive, with higher rate of recurrence than other skeletal sites (Minhas, 2010). Historically, the major problem with treating giant cell tumors of the hand has been achieving local tumor control without the need for radical resection or amputation (Wittig et al., 2001). 
On plain radiographs, GCT almost invariably presents as a geographic lytic lesion with a well-defined, non-sclerotic margin (80\%-85\% of cases). As with other musculoskeletal neoplasms, CT and MR imaging allow superior delineation and local staging of GCTs. CT is particularly useful for the identification of cortical thinning, pathologic fracture, periosteal reaction, assessing the degree of osseous expansile remodelling, and confirming the absence of matrix mineralization. CT is generally superior to MR imaging in assessing these features. MR imaging frequently reveals a relatively well-defined lesion with a low-signal-intensity margin, representing either osseous sclerosis or a pseudocapsule. the solid components of GCT show a low to intermediate signal intensity at $\mathrm{T} 1$ - and nonfat-suppressed T2-weighted MR imaging. Bone scintigraphy demonstrates increased radionuclide uptake in the vast majority of GCTs, Increased radionuclide uptake peripherally with photopenia centrally, termed the "donut sign," was seen in $57 \%$ of cases ( Dasan et al., 2012).

GCT was originally thought to be a type of osteosarcoma. Some authors have reported that the diagnosis could be made by excluding other possibilities. The radiologic differential diagnosis for such lesion includes aneurysmal bone cysts, benign chondroblastoma, non-osteogenic fibroma, simple bone cyst, and, in some cases, osteosarcoma, brown tumour of hyperparathyroidism, enchondroma, metastatic disease, chondrosarcoma, and giant cell reparative granuloma.(Dahlin DC, 1985) GCT in the hand is well characterised and has a higher risk of malignancy, recurrence and metastatic disease.

In this case, retaining function of the thumb with sufficiently aggressive surgical treatment is extremely difficult (Fnini et al., 2008). The treatment of GCT using intra- regional procedures includes the following: curettage and bone grafting or excisional procedures, such as local excision, wide excision, amputation, and ray resection.1 Intralesional curettage may be improved with local adjuvant treatment, such as phenol (Becker et al., 2008; Trieb et al., 2001), alcohol (Errani et al., 2010; Jones et al., 2006), and cryotherapy (Marcove et al., 1978; Malawer et al., 1999). Bone defects can be supplemented with polymethylmethacrylate (PMMA) cement, autograft, allograft or bone substitute (Algawahmed et al., 2010).

In addition, treatment can be enhanced with the use of monoclonal antibody (Thomas et al., 2010) calcitonin (Nouri et al., 2011) and bisphosphonates (Balke et al., 2010). However, it should be noted that the effectiveness of these methods in the treatment and prevention of recurrence is still under discussion and there is no gold standard for treating GCT (Reichert et al., 2017).

Procedures such as curettage and bone grafting do not give satisfactory results and may contribute to recurrence. Due to the high percentage of recurrence, some authors do not recommend curettage alone.(Athanasian et al., 1997; Averill et al., 1980). Averill et al. (1980) reported success in more than $70 \%$ of recurrent lesions that were treated with wide excision or amputation (Dickson et al., 2008; Averill et al., 1980).

On the other hand, an amputation or ray resection isassociated with loss of motor function and various degrees of injury to the patient. Due to the lack of satisfactory outcomes, a number of authors are trying to determine the risk factors that affect the number of relapses (Dickson et al, 2008; Williams et al., 2010) reported on the expression of p63 immunostaining in the mononuclear cells of giant cell tumours. 
(Dickson et al., 2008). This examination is useful for distinguishing between giant cell tumour and other giant cell-rich tumours, such as aneurysmal bone cysts, chondroblastoma, and reparative giant cell granuloma. On the other hand, Williams showed no significance for gender, age, hand dominance or radiologic findings (Williams et al., 2010). The statistical analysis showed significant differences between specific tissue or expires and recurrence. Positive correlation was noted for involvement of the extensor tendon, flexor tendon, and join capsule.

Evaluation of the treatment outcomes was confounded by the fact that although most recurrences occur within 3 years of treatment, late recurrence of giant cell tumours, even after 15 years later, have been observed in the location where identified lesion had been surgically managed (Scully et al., 1994), others were observed to recur as late as 42 years later (Goldenberg et al., 1970).

One reason for the high number of recurrences is insufficient removal of radical changes during curettage. When using curettage, we cannot assess whether the tumour has been fully removed. Moreover, any recurrence that is combined with involvement of another bone region, as in the case of the thumb, restricts the subsequent procedure options. The histopathological confirmation of a safely excised margin offers the best chance for avoiding recurrence. An additional advantage of a two-stage treatment is avoidance of an incorrect diagnosis because the results do not always coincide with the biopsy results. Additionally, in the event of misdiagnosis, this approach allows for the use of different treatment techniques (Reichert et al., 2017).

In our cases, we still doing limb salvage surgery with wide excision or curre- tage and also reconstruction with allograft or autograft with fibular graft. Misdiagnosis and resection of the tumour with too small of a safety margin contributes to recurrence and requires changing the procedure to a more invasive technique. The histopathological confirmation of dianosis and radical removal of the tumour increase the probability that there will not be any recurrence.

\section{CONCLUSION}

Giant cell tumors (GCT) of hand showed that primary Giant cell tumours involving bones of the hand are rare lesions which are generally diagnosed at an advanced stage. It should be noted that the effectiveness of these methods in the treatment and prevention of recurrence is still under discussion and there is no gold standard for treating GCT.

Misdiagnosis and resection of the tumour with too small of a safety margin contributes to recurrence and requires changing the procedure to a more invasive technique. The histopathological confirmation of diagnosis and radical removal of the tumour increase the probability that there will not be any recurrence.

\section{REFERENCE}

Athanasian EA, Wold LE, Amadio PC (1997). Giant cell tumors of the bones of the hand. J Hand Surg. 22A: 91-98.

Averill RM, Smith RJ, Campbell CJ (1980).

Giant-cell tumors of the bones of the hand. J Hand Surg. 5A: 39-50.

Yanagisawa M, Okada K, Tajino T, Torigoe T, Kawai A, Nishida J (2011). A clinicopathological study of giant cell tumor of small bones. Ups J Med Sci. 116: 265e268. http://dx.doi.org/10.3109/03009734.2011.596290.

Frassica FJ, Sanjay BK, Unni KK, et al. (1993). Benign giant cell tumor. Orthopedics. 16(10): 1179-83. 
Reichert P, Kowalski P, Gosk J (2017). The giant cell tumour of the proximal phalanx of the thumb treated by a 2stage operation. Acta Orthopaedica et Traumatologica Turcica. 51: 425-428

Malawer M, Wittig J, Bickles J (2012). Operative Techniques in Orthopaedic Surgical Oncology. Lippincot \&: Wilkins, a Wolters Kluwer.

Moon JC, Kim SR, Chung MJ, Lee YC (2012). Multiple pulmonary metastases from giant cell tumor of a hand. Am J Med Sci. 343(2):171-3.

Becker WT, Dohle J, Bernd L, et al. (2008). Local recurrence of giant cell tumor of bone after intralesional treatment with and without adjuvant therapy. J Bone Jt Surg Am. 90: $1060 e 1067$. http://dx.doi.org/10.2106/JBJS.D.02 771.

Trieb K, Bitzan P, Lang S, Dominkus M, Kotz R (2001). Recurrence of curetted and bone-grafted giant-cell tumours with and without adjuvant phenol therapy. Eur J Surg Oncol. 27: 200202.

Errani C, Ruggieri P, Asenzio MA, et al. (2010). Giant cell tumor of the extremity: a review of 349 cases from a single institution. Cancer Treat Rev. 36: 1e7. http://dx.doi.org/10.1016/j.ctrv.2009.09.002.

Jones KB, DeYoung BR, Morcuende JA, Buckwalter JA (2006). Ethanol as a local adjuvant for giant cell tumor of bone. Iowa Orthop J. 26: 69-76.

Marcove RC, Weis LD, Vaghaiwalla MR, Pearson R, Huvos AG. Cryosurgery in the treatment of giant cell tumors of bone. A report of 52 consecutive cases. Cancer. 1978;41:957-969.

Malawer MM, Bickels J, Meller I, Buch RG, Henshaw RM, Kollender Y (1999). Cryosurgery in the treatment of giant cell tumor. A long-term follow-up

study. Clin Orthop Relat Res. 359:176188.

Algawahmed H, Turcotte R, Farrokhyar F, Ghert M (2010). High-speed burring with and without the use of surgical adjuvants in the intralesional management of giant cell tumor of bone: a systematic review and meta-analysis. Sarcoma. http://dx.doi.org/10.1155/2010/586090. Article ID 586090.

Thomas S, Henshaw R, Skubitz K, et al. (2010). Denosumab in patients with giant cell tumour of bone:an openlabel, phase 2 study. Oncol Lancet. 11: $275 \mathrm{e} 280$.

Nouri H, Meherzi MH, Ouertatani M, et al. (2011). Use of calcitonin in giant cell tumors of bone. Orthop Traumatol Surg Res. 97: 520-526.

Balke M, Campanacci L, Gebert C, et al. (2010). Bisphosphonate treatment of aggressive primary, recurrent and metastatic giant cell tumour of bone. BMC Cancer. 2010;10:462-470.

Patel MR, Desai SS, Gordon SL, Nimberg GA, Sclafani SJ, Vigorita VJ, et al. (1987). Management of skeletal giant cell tumors of the phalanges of theand. J Hand Surg Am. 12:70-7.

Saikia KC, Bhuyan SK, Goswami S, Bora A (2009). Rare site giant cell tumors: Report of two cases on phalanges of the finger and review of literature.J Orthop Traumatol. 10: 193-7. (Giant cell tumour of a proximal phalanx treated with enbloc resection, buddhika).

Bloodgood JC (1919). Bone tumours central (medullary) giant cell tumor (sarcoma) of lower end of ulna, with evidence that completedestruction of the bony shell or perforation of the bony shell is not asign of increased malignancy. Ann Surg. 69: 345-59. 
Coley BL, Higisibotham NL, Koguse T (1958). Giant cell tumor of bone. Am Jsurg. 96:479-91.

Goldenberg RR, Campbell CJ, Bonfiglio M (1970). Giant-cell tumor of bone.An analysis of two hundred and eighteen cases. J Bone Joint Surg Am. 52: 61964.

Dahlin DC (1996). Dahlins Bone Tumours: General Aspects and Data of11,087 Cases. 5th ed. Philadelphia: Lippincott-Raven.

Campanacci M, Baldini N, Boriani S, Sudanese A (1987). Giant-cell tumor of bone. J Bone Joint Surg Am. 69:10614.

Yasuda T, Kanamori M, Ishizawa S, Nogami S, Hori T, Suzuki K, et al. (2008). Multicentric diffuse-type giant cell tumor of the hand. Mod Rheumatol. 18: 67-71.

Lopez-Barea F, Rodriguez-Peralto JL, Garcia-Giron J, Guemes-Gordo F (1992). Benign metastasizing giant-cell tumor of the hand. Report of a case and review of the literature. Clin Orthop Relat Res. 274:270-4.

Wittig J, Simpson B, Bickels J, KellarGraney K, Malawer M (2001). Giant Cell Tumor of the Hand: Superior Results With Curettage, Cryosurgery, and Cementation. The Journal of Hand Surgery. 26A: 546-554.

Minhas M, Mehboob G, Ansari I (2010). Giant cell tumours in hand bones. Journal of the College of Physicians and Surgeons Pakistan. 20(7): 460463.
Dasan T, Vijay K, Satish C, Nagraj B, Nataraj $B$ (2012). Comprehensive case report of a giant cell tumor involving the proximal phalanx of the left great toe managed with fibular grafting. The Internet Journal of Radiology. 14(1): 1-7.

Dahl in DC (1985). Giant cell tumor of bone: high lights of 407 cases. AJR Am J Roentgenol. 144: 955-960.

Fnini S, Labsaili N, Messoudi A, Largab A (2008). Giant cell tumor of the thumb proximal phalanx: resection-iliac graft and double arthrodesis. Chir Main. 27: 54e57. http://dx.doi.org/10.1016/j.main.2007.10.007.

Dickson BC, Li SQ, Wunder JS (2008). Giant cell tumor of bone express p63. Mod Pathol. 21: 369-375.

Williams J, Hodari A, Janevski P, Siddiqui A (2010). Recurrence of giant cell tumors in the hand: a prospective study. J Hand Surg. 35A: 451-456.

Scully SP, Mott MP, Temple HT, O'Keefe RJ, O'Donnell RJ, Mankin HJ (1994). Late recurrence of giant-cell tumor of bone: a report of four cases. J Bone Jt Surg. 76A: 1231-1233.

Jackson K, Key CH, Fontaine M, Pope R (2012). Recurrence of a giant cell tumor of the hand after 42 Years: case report. J Hand Surg. 37A: 783-786.

Goldenberg RR, Campbell CJ, Boniglio M, et al. (1970). Giant-cell tumor of bone. An analysis of two hundred and eighteen cases. J Bone Joint Surg Am. 52(4): 619-64. 